\title{
Cross-cultural communication during the lend-lease supplies via the Arctic route
}

\author{
Elena Aleksandrova ${ }^{1, *}$, Elena Kokanova ${ }^{2}$, \\ ${ }^{1}$ Murmansk Arctic State University, Murmansk, Russia \\ ${ }^{2}$ Norhtern (Arctic) Federal University, Arkhangelsk, Russia
}

\begin{abstract}
The article presents the overview of the ways in which cross-cultural communication was carried out during the lend-lease supplies via the Arctic convoys. It reflects on the importance of non-professional translation and cross-cultural mediation in such spheres as medicine, hospitality, transport, customs, etc. The skills of a professional translator are viewed in contrast to those necessary for successful linguistic mediation. The authors emphasise the role of international seamen's clubs in the establishment of contacts between the represantatives of different nationalites. Much of the information provided in the article has never been published before as it was obtained in the state archives of Murmansk and Arkhangelsk, some of which have been open for research in recent years. A number of documents concerning details of crosscultural mediation during the period of the Arctic convoys were lost or destroyed during the Great Patriotic War, so some information can be obtained only from the participants of the events of that period who are not numerous nowadays.
\end{abstract}

\section{Introduction}

International events such as fora, conferences, meetings and talks are impossible to imagine without interpreters and translators. The results of the international events depend to a high extent on the professional skills of those who provide cross-cultural mediation both in written and oral communication. At the same time, in some conditions cross-cultural mediation is carried out not by professional translators and interpreters but by skilled professionals in other spheres who know a foreign language well enough to provide successful communication.

Non-professional translation and interpreting was one of the types of cross-cultural mediation during the lendlease supplies. Murmansk and Arkhangelsk as port-cities played a major role in supplying the country with arms and food. Professional translation was mostly provided in the military sphere. But the arrival of vessels with lend-lease supplies called for other types of translations as well in different spheres: medicine, hospitality industry, customs, transport, etc.

Arctic convoys during the Second World War (the Great Patriotic War in the Soviet Union) provided help to the Soviet Union by bringing goods and military supplies to the ports of Murmansk and Arkhangelsk. Starting with August 1941 until May 1942, 78 convoys sailed to the USSR. All in all they consisted of 1400 vessels bringing the supplies within the framework of the lend -lease programmes. Arctic convoys shipped about half of all the aid which the Soviet Union received in the terms of the lend-lease agreement. The first port of the
Soviet Union that received the first convoys was Arkhangelsk. In December 1942 the first ships started calling at the port of Murmansk. The supplies included bombs, airplanes or disassembled airplane parts, military equipment and clothes. The convoys which were leaving the Soviet Union took back timber and gold.

One of the ways to provide cross-cultural mediation during lend-lease supplies was the so called nonprofessional translation. Murmansk as well as Arkhangelsk ports played a crucial role in the supplies of the country with weapons and provision. Nonprofessional translators became an integral part of facilitating the communication between the representatives of different nations participating in the supplies via the Arctic route. Professional translation was mostly carried out in the military sphere - these were the graduates of special short-term courses of translation and interpreting. But the growing number of ships entering the ports of Murmansk and Arkhangelsk meant that the authorities of the cities had to provide cross-cultural mediators for such spheres as medicine, customs, entertainment sphere, etc.

The modern standards and requirements to the interpreters and translators concern many aspects of their professional activity, such as language skills, ethics, communication skills, etc. A widely used metaphor describes an interpreter or a translator as Shiva with many arms, thus reflecting how multi-fauceted the profession and the job is. There being no official professional standard for interpreting and translating in the Russian Federation for the time being, we can refer to the definition dictionary of translation studies (edited by

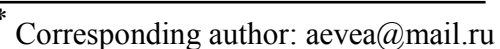


L. Nelyubin) to find out the requirements the professional in this sphere has to meet. The dictionary lists many skills necessary for a translator which can be summed up as the mission of the profession: to understand the meaning conveyed by the Source language and transfer it by means of the Target language [1].

The above mentioned mission can be fulfilled by meeting the following requirements:

- vocabulary of the Target language;

- grammar and stylistics of the Target language;

- the basics of the translation theory;

- skills in the necessary translation techniques (using dictionaries and reference materials, translation rules and translation methods);

- using the variety of the Target language ;

- understanding the subject area;

- avoiding literal translation and all kinds of word-for-word translation;

- understanding the realia and the cultural and national specifics of the country of the target language [1].

\section{Professional translation interpreting}

Professional interpreters and translators for the military sphere were trained in several special schools which underwent a serious transformation after the II World War broke out in Europe. In March 1940 a new faculty opened in Moscow Pedagogical Institute with the aim to train teachers in three foreign languages for military educational institutions. During the great Patriotic War the Faculty opened short-term courses for military translators. They studied hard in three shifts, for 10 hours a day each shift. The first course graduates were ready for the front in December, 1941. The requirements for a military translator were overwhelming and included both translating written documents and interpreting meetings, talks and interrogations. All in all, the short-term courses prepared more than 2.5 thousand translators in three years, many of them with German as a B-language. This means that the number of skilled translation professionals was not enough to provide all the spheres of communication during the lend-lease supplies [2].

\section{Non-professional cross-cultural mediation in specific spheres}

\subsection{Medicine}

The convoy vessels that called at the ports of Murmansk and Arkhangelsk often brought wounded sailors on board. It meant that they required medical help to be provided for them. Most doctors and nurses did not know English as German was the foreign language that was taught at schools and other educational institutions before and during the war. That is why the patients of the military hospitals often had to interpret for their fellows. For example, Polish-speaking sailors who served on board the English and American vessels could provide some translation as they could speak both English and some Russian.

Some convoy veterans also recollected a doctor at the hospital in Murmansk who knew English and could talk to the wounded seamen thus substituting the interpreters. No information has been obtained yet to provide the details concerning the name of the doctor, where he was trained.

\subsection{Murmansk customs}

There are not many sources of information about the work of customs officials during the period of Arctic Convoys. At the end of 1940 - beginning of 1941 the staff of Murmansk Customs office included 22 people. At that time the vessels that were based in the port of Murmansk belonged to Murmansk Shipping Company, Narkommorflot, Murmansk Arctic Shipping Company and Northern Shipping Company (Archangelsk). When the war broke out many customs offices of the Soviet Union stopped their operations either because the territory was occupied by the Nazi troops or there was no need in customs operations in the region. The customs offices in Murmansk and Archangelsk continued their operations though most customs officers were mobilized in the very first days of the war. Thus, 12 inspectors of Murmansk customs office were mobilized, those who were not subject to mobilization for health or other reasons were sent to Arkhangelsk. In autumn 1941 the staff of the customs office of Murmansk consisted only of three people. The staff was decreased as the connection of the Kola Peninsula with the mainland was almost cut off: the railroad was captured by the Finnish troops and no cargoes could be transported; the port was carrying out the transportation of the military cargo, and all the export and import operations were carried out in Arkhangelsk.

The customs offices had to fulfill all the corresponding procedures in order to provide the necessary documentation for further use of the cargo unloaded from the foreign vessels.

In winter 1942 the first caravans called at the port of Murmansk. The main functions of the customs officials at that time included control and taxation of the goods.

The following operations were carried out in order to provide customs control of the cargo delivered by the convoy vessels:

- checking documents and information;

- oral inquiries;

- customs examination;

- cargo inspection;

- checking authentification of the cargo;

- preparing reports [3].

As is obvious from these forms of customs control, the requirements to the customs inspectors, apart from knowledge of customs procedures, included knowledge of foreign languages, that is, of the English language. 
The strategic importance of the cargo delivered to the port of Murmansk called for increasing the staff of the customs office and reinforcing it with skilled professionals from other customs offices of the Soviet Union. As a result, in 1942 the staff of the Murmansk office consisted of 30 specialists who were transferred mostly from Leningrad and Arkhangelsk. It is important to mention, though, that until August 1942 there was no translator in the staff of Murmansk customs office which means that all the translation and communication into English and in English was carried out by the inspectors.

Requirements to the customs inspectors. Sufficient knowledge of a foreign language was conditioned by the amount of international contacts which took place during customs procedures. The customs officials were supposed to be ready for communication in English both in written and in oral forms. The specificity of the communication consisted in the use of professional and sector-specific vocabulary which, on the one hand, could be found in special reference books and dictionaries, and, on the other hand, was beyond the level of the curriculum of vocational training schools and institutes.

Working conditions. The lack of time for customs procedures presented a difficulty for the inspectors: 2 hours were allocated for the inspection of a Soviet vessel, 1 hour - for the inspection of the foreign vessel. All the customs procedures in war-time Murmansk were carried out by two inspectors per vessel. As the port was in great demand workers to participate in unloading the vessels, the customs officers often worked extra hours assisting the port workers in unloading operations.

Master's declaration was provided as a part of customs procedures and customs inspection. It included the following documents:

- the list of passengers and their luggage;

- ship's roll;

- customs documents (certificates of the origin of the cargo and export license);

- bill of lading;

- ship's papers (ship's licence, logbook etc.);

- health bill;

- the list of cargo shipped without bill of lading,

- provision inventory,

- weapons and explosives inventory.

A separate procedure was assumed if the cargo was damaged during the transportation. In the presence of the master of the ship and a representative of the port a statement notice of customs inspection was drawn up. The statement notice was to include the degree of damage, the usability of the goods or the supplies taking into consideration the damage to them, and the possibility to use the damaged cargo for different purposes and at a different price [4].

\subsection{Murmansk international club}

Seamen's international clubs in Murmansk and Arkhangelsk played an important role in the leisure time of the seamen of British and American vessels.

Murmansk international club was established at the beginning of the Great Patriotic War by a group of specialists who came to Murmansk to organise its work. Special receptions were organised when a new convoy arrived at the port, and official representatives of the military missions of the USA and the UK as well as Soviet officials attended them. The Mayor of Murmansk, A. Koltsov, attended such parties on a regularly basis as he was responsible for many issues connected with the convoys entering the port. He used to open and close the official banquets according to the following tradition: all the participants greeted each other (even if interpreters were not available), then they took their seats at the tables and the mayor delivered a speech welcoming the guests to the city. He knew English well enough to deliver speeches in English as he had had some experience of working on foreign shipping vessels which called at the ports of English-speaking countries.

Murmansk international club was headed by Nikolai Kurt, a former seaman with technical education who obviously had learnt English during his voyages. His responsibilities included different things apart from running the club: he was responsible for mobilizing the foreign seamen to unload their vessels ahead of the schedule, a task which he often successfully performed. He also initiated blood donation for the wounded soldiers of the Red Army, and, as a result, since February, 1943, 200 foreign seamen donated their blood. Interclub workers organized collecting presents and parcels for the wounded soldiers of the Red Army.

Another active Interclub worker, Simon Khurgin, spent much time at the port talking to the foreign seamen, persuading them to work longer shifts to unload the vessel ahead of the schedule, and to participate in blood donation. He also organized many events in the club, such as lectures, reports, discussions, watching films. It must be noted that often the films did not have a prerecorded translation and were interpreted simultaneously by the Interclub workers.

Tatiana Gorinova came to work in Murmansk from Arkhangelsk Interclub in April, 1943. Her responsibilities included organizing political work with the foreign seamen raising their sympathies to the Soviet Union. She translated the texts of political reports and Soviet films into English. She also delivered the front news to the foreign seamen emphasizing the heroic actions of the Soviet soldiers $[5,6]$.

\section{Seamen's international clubs and cross-cultural mediation}


According to archival documents, Arkhangelsk international club was officially established on July, 25, 1925. At that time the responsibilities of the club workers included anti-capitalist propaganda among the foreign seamen. At the beginning of the Great Patriotic War the club was headed by Vasiliy Kokorev, and in late autumn 1941 it was given a separate 3-storeyed stone building with steam heating which underwent some reconstruction and was ready to start its work by January, 1, 1942. The club was situated in the centre of the city on the bank of the Dvina river and included a restaurant for 100 seats, a gym for 60-70 people, a barber's, a big cinema-hall and even rooms for exhibitions. All in all, it could provide entertainment for up to 600 people. As some foreign seamen recollected, the club looked better than some similar clubs in the USA and UK $[7,8]$.

The first big group of foreign seamen attended the club on March, 21, 1942. At that time (since February till August, 1942) the club was headed by Tatiana Gorinova who later came to work in the Interclub in Murmansk. The staff of the club included 24 people.

Table 1. Arkhangelsk Interclub staff and salary list (as of April, 1 1942).

\begin{tabular}{|c|c|c|c|}
\hline Job & $\begin{array}{c}\text { Numb } \\
\text { er }\end{array}$ & $\begin{array}{l}\text { Salary, } \\
\text { rubles }\end{array}$ & $\begin{array}{c}\text { Name (if } \\
\text { available) }\end{array}$ \\
\hline Director & 1 & 1100 & T. Gorinova \\
\hline $\begin{array}{c}\text { Chief } \\
\text { instructor }\end{array}$ & 1 & 900 & T. Ruzskaya \\
\hline Instructor & 1 & 800 & T. Novikova \\
\hline $\begin{array}{l}\text { Maintenanc } \\
\text { e specialist }\end{array}$ & 1 & 600 & V. Kokarev \\
\hline Accountant & 1 & 500 & A.Lakhutina \\
\hline Cashier & 1 & 350 & O. Medvedkova \\
\hline Plumber & 1 & 400 & Babushkov \\
\hline Chief stoker & 1 & 250 & vacancy \\
\hline Stoker & 2 & 200 & vacancy \\
\hline Cleaner & 5 & 150 & $\begin{array}{l}\text { Perfilyeva } \\
\text { Korobitsyna } \\
\text { Martykova } \\
\text { Smolina } \\
\text { Tretyakova } \\
\end{array}$ \\
\hline $\begin{array}{l}\text { Yard- } \\
\text { keeper }\end{array}$ & 1 & 250 & Vasilkova \\
\hline $\begin{array}{l}\text { Doorman- } \\
\text { guard }\end{array}$ & 1 & 250 & F. Ordin \\
\hline Doorman & 1 & 250 & I. Tochilov \\
\hline $\begin{array}{l}\text { Cloakroom } \\
\text { attendant }\end{array}$ & 3 & 150 & $\begin{array}{l}\text { Vyatkina } \\
\text { Potapova } \\
\text { Zolotilova }\end{array}$ \\
\hline $\begin{array}{c}\text { Chief } \\
\text { librarian }\end{array}$ & 1 & 300 & N. Blinchikova \\
\hline
\end{tabular}

\begin{tabular}{|c|c|c|l|}
\hline $\begin{array}{c}\text { Cinema-hall } \\
\text { operator }\end{array}$ & 1 & 450 & B. Plyamovat \\
\hline $\begin{array}{c}\text { Assistant of } \\
\text { cinema-hall } \\
\text { operator }\end{array}$ & 1 & 150 & V. Prikazchikov \\
\hline Total & 24 & 200 & \\
\hline $\begin{array}{c}\text { Extra } \\
\text { payment for } \\
\text { foreign } \\
\text { language } \\
\text { knowledge }\end{array}$ & & \\
\hline
\end{tabular}

As is seen from the table above, there was a special extra payment for those who could speak a foreign language.

There was also a branch of the international club in Molotovsk with the staff consisting of two people (instructor and maintenance worker) $[9,10]$.

\section{Discussion}

The lack of professional interpreters and translators did not prevent successful communication between all the parties of the complicated system of lend-lease supplies via Murmansk and Arkhangelsk due to several factors. First, the necessity to continue shipping operations notwithstanding the severe conditions, both geographical and military, spurred port workers to learn the basics of the English language. Second, many seamen who had sailed abroad had a certain command of English and could help with communication in different spheres. Third, seamen's international clubs representatives also assisted communication between the foreigners and the local officials.

Professional communication in the sphere of customs control during the period of lend-lease supplies via the Arctic convoys was complicated by the conditions in which the customs officials were performing their duties: the lack of time, shortage of qualified professionals, weather conditions, constant air raids, the responsibility for the strategically important cargo and corresponding documents. All these factors proved that a customs official is supposed to have other qualities apart from professional ones: stress resistance and patience, tactfulness, attention to detail and observation.

Admission to the new archival information on the Arctic convoys can provide further details of crosscultural mediation during that period.

\section{Acknowledgement}

The research is funded by the Russian Fund of Fundamental Research (project 18-012-00213 A)

\section{References}

1. L.L. Nelyubin Dictionary of Translation Terms (2003) 232p. 
2. V.K. Antyufeyev Military interpreters training during the Great Patriotic War. Retrieved from: http://www.oboznik.ru/?p=43266 (2018)

3. V.V. Golovin Tamozhennyaya Slujba na Murmane 1941-1945 (2001) 164 p.

4. V.V. Golovin Istoriya Murmanskoy tamojni, 19192005 (2006) 295 p.
5. GAMO F -36 Op. 1. D.90 L. 3-20

6. GAMO F -36 Op. 2. D.20 L. 4-18

7. GAAO F. 1649. Op. 2. D. 1. L. 6, Ob. L. 6.

8. GAAO ODSPI F. 1 Op.1. D. 1481. L. 271.

9. GAAO ODSPI F. 1 Op.1. D. 1670. L. 59.

10. GAAO ODSPI F. 5 Op.1. D. 529. L. 78. 